\title{
The Influence of Price and Service Quality on Customer Satisfaction at PT Sarana Estate
}

\author{
Aris Ariyanto \\ Universitas Pamulang \\ E-mail: dosen02492@unpam.ac.id
}

\begin{abstract}
This study aims to determine the effect of price and service quality on customer satisfaction at PT. Estate Facilities. The method used is explanatory research with analytical techniques using statistical analysis with regression testing, correlation, determination, and hypothesis testing. The results of this study have a significant effect on customer satisfaction by $41.5 \%$, the hypothesis test obtained $t_{\text {count }}>t_{\text {table }}$ or $(8.130>$ 1.986). Service quality has a significant effect on customer satisfaction by $43.1 \%$, the hypothesis test is obtained $t_{\text {count }}>t_{\text {table }}$ or $(8,401>1,986)$. Price and quality of service simultaneously have a significant effect on customer satisfaction by $52.8 \%$, the hypothesis test is obtained $F_{\text {count }}>F_{\text {table }}$ or $(51,366>2,700)$.
\end{abstract}

Keywords: Price; service quality; customer satisfaction

\section{INTRODUCTION}

The demand for housing is an offer made by developers in housing property to help the community in meeting their housing needs. However, inequality in housing provision occurs. The high demand is not directly proportional to the provision of housing. The causes are also varied, ranging from difficult processes, policies that are still less effective, the limited ability of consumers and financing factors to be the main obstacle. With this shift in needs, the management of PT. Sarana Estate is very important to utilize and increase the variables above in order to increase customer preferences and satisfaction that can increase market changes.

(Udang-Undang Nomor 1 Tahun 2011 tentang Perumahan dan Kawasan Pemukiman, 2011) states that the government needs to play a greater role in providing and facilitating housing and settlement areas for the community through the implementation of area-based housing and settlement areas as well as community self-sufficiency so that they are a functional unit in the form of physical spatial structure, economic life, and socio-cultural capabilities. guaranteeing environmental sustainability in line with the spirit of democracy, regional autonomy, and openness in the order of life in the community, nation, and state.

One of the underlying factors is price (Arianto, 2013; Kim, Jang, Kang, \& Kim, 2020; Scriven, Clemente, Dawes, Trinh, \& Sharp, 2017). Price is one of the factors that is enough to influence the community to use or own an item that is deemed appropriate to their needs (Balaguer \& Pernías, 2013; Chenavaz, Feichtinger, Hartl, \& Kort, 2020; Zhu, Jiao, \& Yuan, 2019). If the price of the product offered by the developer is affordable by the people, it can be said that the public will use the product and of course it is adjusted to the price according to their abilities and needs. 
218 Jurnal Administrare: Jurnal Pemikiran Ilmiah dan Pendidikan Administrasi Perkantoran

Volume 6 Number 2 July- December 2019. Pages 217-228

Table 1

Number of Home Sales

\begin{tabular}{ccllcl}
\hline Year & Price & Discount & Request & Realization & Amount $(\mathrm{Rp})$ \\
\hline 2016 & 110.000 .000 & No Promo & 486 Unit & 347 Unit & 38.170 .000 .000 \\
2017 & 123.000 .000 & Dp 0\% & 527 Unit & 379 Unit & 46.617 .000 .000 \\
2018 & 130.000 .000 & Cash & 435 Unit & 328 Unit & 42.460 .000 .000 \\
Tack & & & 1.448 Unit & 1.123 unit & 127.247 .000 .000
\end{tabular}

Based on observations with one of the parties from PT. Sarana Estate stated, that the increasing number of requests could not be balanced with the realization of the housing embodiment submitted by the customer. Judging from 2016 with a house price of Rp. $110,000,000$ total demand for housing purchases was 486 units but only realized 347 units with a value of Rp. 38,170,000,000. This also happened the following year in 2017 with a house price of Rp. 123,000,000 of 527 units and the realization of 379 units with a value of 46,617,000,000 then in 2018 with a house price of Rp. 130,000,000, the number of housing demand has decreased quite high, namely 435 units but the realization was only 328 units with a value of Rp. 42,460,000,000.

Quality of service is something perceived by the customer (Herdiyanti, Adityaputri, \& Astuti, 2017; Hewagama, Boxall, Cheung, \& Hutchison, 2019; Nunkoo, Teeroovengadum, Ringle, \& Sunnassee, 2019). Customers will judge the perceived quality of service based on what they describe in their minds. Customers will turn to competitors who are better able to understand the specific needs of customers and provide better services (Artiningtyas, Minarsih, \& Hasiolan, 2014; Kaihatu, 2012; Tjiptono, 2004).

The high level of unrealized demand can be reflected by the increasingly sensitive demands of customers to factors that can provide satisfaction or reduce the risk of failure in business. During this time the company's performance evaluation to build customer satisfaction is felt to be still lacking (Hasnelly \& Yusuf, 2012; Minarti \& Segoro, 2014; Purnasari \& Yuliando, 2015). This will certainly have the effect of dissatisfied customers and gradually if not immediately evaluated, customers will be increasingly reduced.

Creating customer satisfaction is not only through handling customer complaints, but quality products and service improvements are one of the keys in maintaining customers (Putro, Semuel, \& Brahmana, 2014; Rasyid, 2017; Trianah, Pranitasari, \& Zahrani Marichs, 2017). Current conditions and facts still occur such as inaccurate information, inadequate infrastructure, the collection of old file requirements and so on are still poorly handled.

Marketing is a business function related to consumers (Kotler \& Keller, 2009; Sutisna, 2003; Swastha, Basu, 2014). The success of a company is largely determined by the achievements of the marketing field. Marketing is a process of studying the needs and desires of consumers, and satisfying consumers with quality products and services and at competitive prices.

The quality of employee service to customers has an asymmetrical effect on customer satisfaction, namely poor service has a greater impact on customer satisfaction than services that are categorized as good, implementing the strategy with the best category will increase customer satisfaction and loyalty (Brata, 2003; Lupiyoadi, 2013; Putro et al., 2014; Trianah et al., 2017). 
PT. Sarana Estate in an effort to improve services, the company creates service standards by providing the best, proactive, and optimal service, giving rise to an impression of excellence.

\section{METHOD}

The type of research used is associative, where the aim is to find out the relationship between variables. A population is a group of objects that are determined through certain criteria that will be categorized into objects that will be examined. According to (Sugiyono, 2016), population is the number of generalized areas consisting of objects or subjects that have the quality and characteristics determined by the researcher and then conclusions drawn. The population in the study amounted to 95 respondents PT. Estate Facilities. According to (Sugiyono, 2016), sample is the number and characteristics possessed by the population. While (Arikunto, 2006) argues that, the sample is part or representative of the population under study. The sampling technique in this study is saturated sampling, where all members of the population are sampled. Thus the sample in this study amounted to 95 respondents. In analyzing the data used the instrument test, classical assumption test, regression, coefficient of determination and hypothesis testing.

\section{RESULT AND DISCUSSION}

PT. Sarana Estate as one of the Permata Mutiara Maja housing developers is one of the companies that implement the Integrated New Town concept that develops housing locations close to stations that are expected to facilitate daily customer access. With affordable housing prices will certainly affect the high demand for housing in Maja Mutiara Gems.

\section{Instrument Test}

In this test validity and reliability tests are used. A validity test is intended to determine the accuracy of the data about the compatibility between what you want to be measured with the results of the measurement. According to (Sugiyono, 2017), valid means that there are similarities between the data collected and the actual data. While (Ghozali, 2018) argues, a questionnaire is said to be valid if the questions on the questionnaire are able to reveal something that will be measured by the questionnaire. To conduct a validity test the significance value of 2 tailed is compared with 0.05 with the provisions that if the significance value of 2 is Talied $<0.05$, then the instrument is valid; if the significance value of 2 Talied $>0.05$, then the instrument is invalid.

From the test results obtained for each item statement of all variables obtained 2 tailed significance value of $0,000<0.05$, thus the instrument is valid.

The next test is the reliability test. The reliability test analysis model used in this study is the Cronbach Alpha model. According to (Ghozali, 2018), reliability is a tool to test the consistency of respondents' answers to questions in the questionnaire. A questionnaire is said to be reliable if a person's answer to a question is consistent or stable over time. The measurements were carried out with Cronbach's Alpha analysis. (Ghozali, 2018) classifies Cronbach's Alpha value, if Cronbach's Alpha value > 0.60, then declared reliable; If Cronbach's Alpha value <0.60, then declared unreliable, 


\section{0|Jurnal Administrare: Jurnal Pemikiran Ilmiah dan Pendidikan Administrasi Perkantoran Volume 6 Number 2 July- December 2019. Pages 217-228}

The test results are as follows:

Table 2.

Reliability Test Results

\begin{tabular}{lccl}
\hline \multicolumn{1}{c}{ Variable } & $\begin{array}{c}\text { Cronbach's } \\
\text { Alpha }\end{array}$ & $\begin{array}{c}\text { Alpha Critical } \\
\text { Standards }\end{array}$ & Information \\
\hline Price (X1) & 0,729 & 0,600 & Reliable \\
Quality of service (X2) & 0,674 & 0,600 & Reliable \\
Customer Satisfaction (Y) & 0,692 & 0,600 & Reliable \\
\hline
\end{tabular}

Based on the results of the above objectives, the price variable (X1) is obtained Cronbach alpha 0.729 , service quality (X2) is obtained Cronbach alpha 0.674 and customer satisfaction (Y) is obtained Cronbach alpha 0.692, where all Cronbach alpha values> 0.60 . Thus declared reliable.

\section{Classic Assumption Test}

The classic assumption test is intended to determine the accuracy of the data. According to (Santoso, 2012), a regression model will be used for forecasting, a good model is a model with minimum forecasting errors. Therefore, a model before use should fulfill a number of assumptions, commonly called classical assumptions. In this study, the classic assumption tests used include: normality test, multicollinearity test, autocorrelation test, and heteroskedasticity test

A normality test is conducted to test whether, in the regression model, the dependent variable and the independent variable are normally distributed or not normally distributed. The results of the normality test with the Kolmogorov-Smirnov Test are as follows:

\section{Table 3.}

\section{Results of Kolmogorov-Smirnov Normality}

Tests of Normality

\begin{tabular}{lrr|r|r|r|c}
\hline & \multicolumn{3}{c}{ Kolmogorov-Smirnov } & \multicolumn{3}{c}{ Shapiro-Wilk } \\
& Statistic & df & \multicolumn{1}{c}{ Sig. } & Statistic & df & Sig. \\
\hline Customer Satisfaction (Y) & .084 & 95 & .097 & .974 & 95 & .057 \\
\hline
\end{tabular}

a. Lilliefors Significance Correction

Based on the test results in the table above obtained significance value $\alpha=0.097$ where the value is greater than the value of $\alpha=0.050$ or $(0.097>0.05)$. Thus, the assumption of the distribution of equations in this test is normal.

Multicollinearity testing is carried out to believe that between independent variables do not have multicollinearity or do not have the effect of correlation between variables determined as models in the study. A multicollinearity test is done by looking at the value of the Tolerance Value and Variance Inflation Factor (VIF). The test results are as follows: 


\section{Table 4.}

Multicollinearity Test Results with Collinierity Statistics.

\begin{tabular}{|c|c|c|c|c|c|}
\hline \multirow[b]{2}{*}{ Model } & \multicolumn{2}{|c|}{$\begin{array}{l}\text { Unstandardized } \\
\text { Coefficients }\end{array}$} & \multirow{2}{*}{$\begin{array}{c}\text { Standardized } \\
\text { Coefficients } \\
\text { Beta } \\
\end{array}$} & \multicolumn{2}{|c|}{$\begin{array}{l}\text { Collinearity } \\
\text { Statistics }\end{array}$} \\
\hline & B & Std. Error & & Tol & VIF \\
\hline $1 \quad$ (Constant) & 9.422 & 2.950 & & & \\
\hline Price (X1) & .362 & .084 & .390 & 633 & 1.580 \\
\hline Quality of Service (X2) & .412 & .088 & .421 & .633 & 1.580 \\
\hline
\end{tabular}

Based on the test results in the table above the tolerance value of each independent variable is $0.633<1.0$ and the value of Variance Inflation Factor (VIF) of $1.580<10$, thus this regression model does not occur multicollinearity.

Autocorrelation testing is used to determine whether there is any correlation between the sample members. Testing is done with the Darbin-Watson test (DW test). The test results are as follows:

\section{Table 5.}

\section{Autocorrelation Test Results}

\begin{tabular}{|c|c|c|c|c|c|}
\hline \multicolumn{6}{|c|}{ Model Summary ${ }^{b}$} \\
\hline Model & $\mathrm{R}$ & R Square & $\begin{array}{l}\text { Adjusted R } \\
\text { Square }\end{array}$ & $\begin{array}{l}\text { Std. Error of the } \\
\text { Estimate }\end{array}$ & Durbin-Watson \\
\hline 1 & $.726^{\mathrm{a}}$ & .528 & .517 & 2.504 & 2.015 \\
\hline
\end{tabular}

a. Predictors: (Constant), Quality of Service (X2), Price (X1)

b. Dependent Variable: Customer Satisfaction (Y)

The test results in the table above obtained the Durbin-Watson value of 1,948 between the values between the 1,550 - 2,460. Thus the regression model stated no autocorrelation disorders.

Heteroscedasticity testing is intended to test whether in a regression model residual variance inequality occurs. The test results are as follows:

Table 6.

\section{Heteroskedasticity Test Results with the Glejser Test Model}

\section{Coefficients $^{\mathrm{a}}$}

\begin{tabular}{|c|c|c|c|c|c|}
\hline \multirow[b]{2}{*}{ Model } & \multicolumn{2}{|c|}{$\begin{array}{l}\text { Unstandardized } \\
\text { Coefficients }\end{array}$} & \multirow{2}{*}{$\begin{array}{c}\text { Standardized } \\
\text { Coefficients } \\
\text { Beta } \\
\end{array}$} & \multirow[b]{2}{*}{$\mathrm{t}$} & \multirow[b]{2}{*}{ Sig. } \\
\hline & B & Std. Error & & & \\
\hline $1 \quad$ (Constant) & 1.549 & 1.756 & & .882 & .380 \\
\hline Price $(X 1)$ & -.064 & .050 & -.167 & -1.287 & .201 \\
\hline Quality of Service (X2) & .075 & .053 & .185 & 1.428 & 157 \\
\hline
\end{tabular}

a. Dependent Variable: Customer Satisfaction (Y)

The test results using the glacier test obtained Sig. $>0.05$. Therefore, the regression model does not have heteroscedasticity disorder. 
222 Jurnal Administrare: Jurnal Pemikiran Ilmiah dan Pendidikan Administrasi Perkantoran

Volume 6 Number 2 July- December 2019. Pages 217-228

\section{Descriptive Analysis}

In this test used to determine the minimum and maximum scores, mean scores and standard deviations of each variable. The results are as follows:

Table 7.

Results of Descriptive Statistics Analysis

Descriptive Statistics

\begin{tabular}{lr|r|r|r|r}
\hline & N & Minimum & Maximum & Mean & Std. Deviation \\
\hline Price (X1) & 95 & 32 & 48 & 38.51 & 3.884 \\
\hline Quality of Service (X2) & 95 & 30 & 45 & 38.43 & 3.678 \\
\hline Customer Satisfaction (Y) & 95 & 32 & 46 & 39.19 & 3.603 \\
\hline Valid N (listwise) & 95 & & & & \\
\hline
\end{tabular}

Prices obtained a minimum variance of 32 and a maximum variance of 48 with a mean score of 3.85 with a standard deviation of 3.884. Quality of service obtained a minimum variance of 30 and a maximum variance of 45 with a mean score of 3.84 with a standard deviation of 3.678. Customer satisfaction obtained a minimum variance of 32 and a maximum variance of 46 with a mean score of 3.92 with a standard deviation of 3.603 .

\section{Multiple Linear Regression Analysis}

This regression test is intended to determine changes in the dependent variable if the independent variable changes. The test results are as follows:

Table 8.

Multiple Linear Regression Testing Results

Coefficients $^{\mathrm{a}}$

\begin{tabular}{|c|c|c|c|c|c|}
\hline \multirow[b]{2}{*}{ Model } & \multicolumn{2}{|c|}{$\begin{array}{l}\text { Unstandardized } \\
\text { Coefficients }\end{array}$} & \multirow{2}{*}{$\begin{array}{c}\text { Standardized } \\
\text { Coefficients } \\
\text { Beta } \\
\end{array}$} & \multirow[b]{2}{*}{$\mathrm{t}$} & \multirow[b]{2}{*}{ Sig. } \\
\hline & $\mathrm{B}$ & Std. Error & & & \\
\hline $1 \quad$ (Constant) & 9.422 & 2.950 & & 3.194 & .002 \\
\hline Price (X1) & .362 & .084 & .390 & 4.326 & .000 \\
\hline Quality of Service (X2) & .412 & .088 & .421 & 4.672 & .000 \\
\hline
\end{tabular}

a. Dependent Variable: Customer Satisfaction (Y)

Based on the test results in the above table, the regression equation $\mathrm{Y}=9.422+0.362 \mathrm{X} 1+$ $0.412 \mathrm{X} 2$ is obtained. A constant of 9,422 means that if there is no price and quality of service, then there is a customer satisfaction value of 9.422 points. The price regression coefficient of 0.362 , this number is positive meaning that every time there is an increase in the price of 0.362 , customer satisfaction will also increase by 0.362 points. Service quality regression coefficient of 0.412 , this number is positive, meaning that every time there is an increase in service quality by 0.412 , customer satisfaction will also increase by 0.412 points. 


\section{Correlation Coefficient Analysis}

Correlation coefficient analysis is intended to determine the degree of relationship strength of the independent variables on the dependent variable either partially or simultaneously. The test results are as follows:

Table 9.

Test Results for Price Correlation Coefficient on Customer Satisfaction.

Correlations $^{\mathbf{b}}$

\begin{tabular}{llr|r}
\hline & & Price (X1) & \multicolumn{1}{c}{$\begin{array}{c}\text { Customer } \\
\text { Satisfaction (Y) }\end{array}$} \\
\hline Price (X1) & Pearson Correlation & 1 & $.645^{* * *}$ \\
\cline { 2 - 4 } & Sig. (2-tailed) & & .000 \\
\hline Customer Satisfaction (Y) & Pearson Correlation & $.645^{* *}$ & 1 \\
\cline { 2 - 4 } & Sig. (2-tailed) & .000 & \\
\hline
\end{tabular}

**. Correlation is significant at the 0.01 level (2-tailed).

b. Listwise $\mathrm{N}=95$

Based on the test results obtained by a correlation value of 0.645 means that prices have a strong relationship with customer satisfaction.

Table 10.

Correlation Coefficient Testing Results Service Quality on Customer Satisfaction.

\section{Correlations $^{\mathrm{b}}$}

\begin{tabular}{llr|r}
\hline & & $\begin{array}{c}\text { Quality of Service } \\
(\mathrm{X} 2)\end{array}$ & \multicolumn{1}{c}{$\begin{array}{c}\text { Customer } \\
\text { Satisfaction (Y) }\end{array}$} \\
\hline Quality of Service (X2) & Pearson Correlation & 1 & $.657^{* *}$ \\
\cline { 2 - 4 } & Sig. (2-tailed) & & .000 \\
\hline Customer Satisfaction (Y) & Pearson Correlation & $.657^{* *}$ & 1 \\
\cline { 2 - 4 } & Sig. (2-tailed) & .000 & \\
\hline
\end{tabular}

**. Correlation is significant at the 0.01 level (2-tailed).

b. Listwise $\mathrm{N}=95$

Based on the test results obtained a correlation value of 0.657 means that service quality has a strong relationship with customer satisfaction. 
224 Jurnal Administrare: Jurnal Pemikiran Ilmiah dan Pendidikan Administrasi Perkantoran Volume 6 Number 2 July- December 2019. Pages 217-228

Table 11.

Simultaneous Correlation Test Results Price and Quality of Service to Customer Satisfaction.

\begin{tabular}{|c|c|c|c|c|}
\hline \multicolumn{5}{|c|}{ Model Summary $^{\mathrm{b}}$} \\
\hline Model & $\mathrm{R}$ & R Square & $\begin{array}{l}\text { Adjusted R } \\
\text { Square }\end{array}$ & Std. Error of the Estimate \\
\hline 1 & $.726^{\mathrm{a}}$ & .528 & .517 & 2.504 \\
\hline
\end{tabular}

a. Predictors: (Constant), Quality of Service (X2), Price (X1)

b. Dependent Variable: Customer Satisfaction (Y)

Based on the test results obtained by a correlation value of 0.726 means that the price and quality of service simultaneously has a strong relationship to customer satisfaction.

\section{Analysis of the Coefficient of Determination}

Analysis of the coefficient of determination is intended to determine the percentage of influence of the independent variable on the dependent variable either partially or simultaneously. The test results are as follows:

Table 12.

Test Results for Price Determination Coefficient on Customer Satisfaction.

\begin{tabular}{lrr|rrr}
\hline \multicolumn{7}{c}{ Model Summary } \\
\hline Model & & & Adjusted R \\
Square & \multicolumn{2}{c}{$\begin{array}{c}\text { Std. Error of the } \\
\text { Estimate }\end{array}$} \\
\hline 1 & R & R Square & Squar & 2.770 \\
\hline
\end{tabular}

a. Predictors: (Constant), Price (X1)

Based on the test results obtained a determination value of 0.415 means that the price has an influence contribution of $41.5 \%$ on customer satisfaction.

Table 13.

Determination Test Results Coefficient of Service Quality on Customer Satisfaction.

Model Summary

\begin{tabular}{lr|rr|rr}
\hline Model & $\mathrm{R}$ & R Square & \multicolumn{2}{c}{$\begin{array}{c}\text { Adjusted R } \\
\text { Square }\end{array}$} & \multicolumn{2}{c}{$\begin{array}{c}\text { Std. Error of the } \\
\text { Estimate }\end{array}$} \\
\hline 1 & $.657^{\mathrm{a}}$ & .431 & .425 & 2.732 \\
\hline a. Predictors: (Constant), Quality of Service (X2) & \multicolumn{2}{l}{}
\end{tabular}

Based on the test results obtained a determination value of 0.431 means that service quality has an influence contribution of $43.1 \%$ to customer satisfaction. 
Table 14.

Test Results for the Determination Coefficient of Price and Service Quality on Customer Satisfaction

Model Summary ${ }^{\mathrm{b}}$

\begin{tabular}{lr|r|rrr}
\hline Model & R & R Square & \multicolumn{2}{c|}{$\begin{array}{c}\text { Adjusted R } \\
\text { Square }\end{array}$} & \multicolumn{2}{c}{$\begin{array}{c}\text { Std. Error of the } \\
\text { Estimate }\end{array}$} \\
\hline 1 & $.726^{\mathrm{a}}$ & .528 & .517 & 2.504 \\
\hline
\end{tabular}

a. Predictors: (Constant), Quality of Service (X2), Price (X1)

b. Dependent Variable: Customer Satisfaction (Y)

Based on the test results obtained a determination value of 0.528 means that the price and quality of service simultaneously have an influence contribution of 52.8\% to customer satisfaction, while the remaining $47.2 \%$ is influenced by other factors.

\section{Hypothesis Testing}

Hypothesis testing with a t-test is used to find out which partial hypotheses are accepted.

Table 15.

Results of Price Hypothesis Tests on Customer Satisfaction

\begin{tabular}{|c|c|c|c|c|c|c|}
\hline \multicolumn{7}{|c|}{ Coefficients $^{\mathrm{a}}$} \\
\hline \multirow[b]{2}{*}{ Model } & & \multicolumn{2}{|c|}{$\begin{array}{l}\text { Unstandardized } \\
\text { Coefficients }\end{array}$} & \multirow{2}{*}{$\begin{array}{c}\text { Standardized } \\
\text { Coefficients } \\
\text { Beta } \\
\end{array}$} & \multirow[b]{2}{*}{$\mathrm{t}$} & \multirow[b]{2}{*}{ Sig. } \\
\hline & & B & Std. Error & & & \\
\hline \multirow[t]{2}{*}{1} & (Constant) & 16.161 & 2.847 & & 5.677 & .000 \\
\hline & Price $(\mathrm{X} 1)$ & .598 & .074 & .645 & 8.130 & .000 \\
\hline
\end{tabular}

a. Dependent Variable: Customer Satisfaction (Y)

Based on the test results in the above table, the value of $t_{\text {count }}>t_{\text {table }}$ or $(8.130>1.986)$ is obtained, thus the first hypothesis is proposed that there is a significant influence on the price of the customer satisfaction received.

Table 16.

Hypothesis Test Results Service Quality on Customer Satisfaction

Coefficients $^{\mathrm{a}}$

\begin{tabular}{|c|c|c|c|c|c|}
\hline \multirow[b]{2}{*}{ Model } & \multicolumn{2}{|c|}{$\begin{array}{l}\text { Unstandardized } \\
\text { Coefficients }\end{array}$} & \multirow{2}{*}{$\begin{array}{c}\text { Standardized } \\
\text { Coefficients } \\
\text { Beta }\end{array}$} & \multirow[b]{2}{*}{$\mathrm{t}$} & \multirow[b]{2}{*}{ Sig. } \\
\hline & $\mathrm{B}$ & Std. Error & & & \\
\hline $1 \quad$ (Constant) & 14.454 & 2.958 & & 4.887 & .000 \\
\hline Quality of Service (X2) & 644 & .077 & 657 & 8.401 & .000 \\
\hline
\end{tabular}

a. Dependent Variable: Customer Satisfaction (Y)

Based on the test results in the above table, the value of $t_{\text {count }}>t_{\text {table }}$ or $(8.401>1.986)$ is obtained, thus the second hypothesis is proposed that there is a significant influence between the quality of service on customer satisfaction received. 


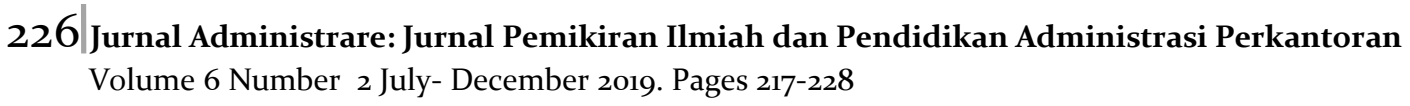

Hypothesis testing with the F test is used to find out which simultaneous hypotheses are accepted

Table 17.

Hypothesis Test Results Price and Quality of Service to Customer Satisfaction

\begin{tabular}{llr|r|r|r|r}
\multicolumn{8}{c}{ ANOVA $^{\mathrm{a}}$} \\
\hline \multirow{2}{*}{ Model } & $\begin{array}{c}\text { Sum of } \\
\text { Squares }\end{array}$ & \multicolumn{1}{c|}{ df } & Mean Square & \multicolumn{1}{c}{ F } & \multicolumn{1}{c}{ Sig. } \\
\hline 1 & Regression & 643.930 & 2 & 321.965 & 51.366 & $.000^{\mathrm{b}}$ \\
\cline { 2 - 8 } & Residual & 576.660 & 92 & 6.268 & & \\
\cline { 2 - 9 } & Total & 1220.589 & 94 & & & \\
\hline
\end{tabular}

a. Dependent Variable: Customer Satisfaction (Y)

b. Predictors: (Constant), Quality of Service (X2), Price (X1)

Based on the test results in the above table, the calculated $F_{\text {count }}>F_{\text {table }}$ or $(51.386>2.700)$, thus the third hypothesis proposed that there is a significant influence between price and service quality on customer satisfaction is received.

\section{CONCLUSION}

Based on the results of the study, the price has a significant effect on customer satisfaction a correlation value of 0.645 or strong with a contribution of $41.5 \%$. Hypothesis testing obtained $t_{\text {count }}>t_{t a b l e}$ or $(8.130>1.986)$. Thus there is a significant effect between price on customer satisfaction at PT. Estate Facilities. Service quality has a significant effect on customer satisfaction with a correlation value of 0.657 or strong with a contribution of $43.1 \%$. Hypothesis testing obtained $t_{\text {count }}>t_{\text {table }}$ or $(8,401>1,986)$. Thus there is a significant influence between service quality on customer satisfaction at PT. Estate Facilities. Price and quality of service have a significant effect on customer satisfaction with a correlation value of 0.726 or strong with a contribution of $52.8 \%$ while the remaining $47.2 \%$ is influenced by other factors. Hypothesis testing obtained by the calculated $F_{\text {count }}>F_{\text {table }}$ or $(51,366>2,700)$. Thus there is a significant effect between price and service quality simultaneously on customer satisfaction at PT. Estate Facilities.

\section{REFERENCES}

Arianto, A. B. (2013). Pengaruh Atribut produk, harga, kebutuhan mencari variasi dan ketidakpuasan konsumen terhadap keputusan perpindahan merek dari Samsung Galaxy Series di Kota Malang. Jurnal Aplikasi Manajemen, 11(2), 294-305.

Arikunto, S. (2006). Prosedur Penelitian Suatu Tindakan Praktik. Jakarta: Rineka Cipta.

Artiningtyas, I., Minarsih, M. M., \& Hasiolan, L. B. (2014). Kepuasan Pelanggan. Pengaruh Kualitas Layanan, Persepsi Harga Dan Kepercayaan Terhadap Kepuasan Pelanggan.

Balaguer, J., \& Pernías, J. C. (2013). Relationship between spatial agglomeration and hotel 
prices. Evidence from business and tourism consumers. Tourism Management, 36, 391400. https://doi.org/https://doi.org/10.1016/j.tourman.2012.10.004

Brata, A. A. (2003). Dasar-Dasar Pelayanan Prima. (Jakarta: PT. Elex Media Komputindo, 2003).

Chenavaz, R. Y., Feichtinger, G., Hartl, R. F., \& Kort, P. M. (2020). Modeling the impact of product quality on dynamic pricing and advertising policies. European Journal of Operational Research, 284(3), 990-1001. https://doi.org/https://doi.org/10.1016/j.ejor.2020.01.035

Ghozali, I. (2018). Aplikasi Analisis Multivariate dengan Program IBM SPSS 25.

Hasnelly, \& Yusuf, E. (2012). Analysis of Market-Based Approach on the Customer Value and Customer Satisfaction and Its Implication on Customer Loyalty of Organic Products in Indonesia. Procedia - Social and Behavioral Sciences, 40, 86-93. https://doi.org/https://doi.org/10.1016/j.sbspro.2012.03.165

Herdiyanti, A., Adityaputri, A. N., \& Astuti, H. M. (2017). Understanding the Quality Gap of Information Technology Services from the Perspective of Service Provider and Consumer. $\begin{array}{llll}\text { Procedia Computer } & \text { Science, } & \text { 601-607. }\end{array}$ https://doi.org/https://doi.org/10.1016/j.procs.2017.12.195

Hewagama, G., Boxall, P., Cheung, G., \& Hutchison, A. (2019). Service recovery through empowerment? HRM, employee performance and job satisfaction in hotels. International Journal of Hospitality Management, 81, 73-82. https://doi.org/https://doi.org/10.1016/j.ijhm.2019.03.006

Kaihatu, T. S. (2012). Kepuasan Konsumen yang Dipengaruhi oleh Kualitas Layanan dengan Brand Image Sebagai Variabel Perantara: Studi Kasus pada Konsumen Rumah Sakit Swasta di Kota Surabaya. Jurnal Mitra Ekonomi Dan Manajemen Bisnis.

Kim, J., Jang, S., Kang, S., \& Kim, S. (James). (2020). Why are hotel room prices different? Exploring spatially varying relationships between room price and hotel attributes. Journal of Business Research, 107, 118-129. https://doi.org/https://doi.org/10.1016/j.jbusres.2018.09.006

Kotler, P., \& Keller, K. L. (2009). Manajemen pemasaran Jilid 1. In Jakarta.

Lupiyoadi, R. (2013). Manajemen Pemasaran Jasa: Berbasis Kompetensi Edisi 3. Penerbit Salemba.

Minarti, S. N., \& Segoro, W. (2014). The Influence of Customer Satisfaction, Switching Cost and Trusts in a Brand on Customer Loyalty - The Survey on Student as im3 Users in Depok, Indonesia. Procedia - Social and Behavioral Sciences, 143, 1015-1019. https://doi.org/https://doi.org/10.1016/j.sbspro.2014.07.546

Nunkoo, R., Teeroovengadum, V., Ringle, C. M., \& Sunnassee, V. (2019). Service quality and customer satisfaction: The moderating effects of hotel star rating. International Journal of Hospitality Management, https://doi.org/https://doi.org/10.1016/j.ijhm.2019.102414

102414. 


\footnotetext{
228|Jurnal Administrare: Jurnal Pemikiran Ilmiah dan Pendidikan Administrasi Perkantoran Volume 6 Number 2 July- December 2019. Pages 217-228
}

Purnasari, H., \& Yuliando, H. (2015). How Relationship Quality on Customer Commitment Influences Positive e-WOM. Agriculture and Agricultural Science Procedia, 3, 149-153. https://doi.org/https://doi.org/10.1016/j.aaspro.2015.01.029

Putro, S., Semuel, H., \& Brahmana, R. (2014). Pengaruh Kualitas Layanan Dan Kualitas Produk Terhadap Kepuasan Pelanggan Dan Loyalitas Konsumen Restoran Happy Garden Surabaya. Jurnal Manajemen Pemasaran.

Rasyid, H. Al. (2017). Pengaruh Kualitas Layanan Dan Pemanfaatan Teknologi Terhadap Kepuasan Dan Loyalitas Pelanggan Go-Jek. Jurnal Ecodemica: Jurnal Ekonomi, Manajemen, Dan Bisnis. https://doi.org/10.31311/jeco.v1i2.2026

Santoso, S. (2012). Panduan Lengkap SPSS Versi 20. In PT Elex Media Komputindo.

Scriven, J., Clemente, M., Dawes, J., Trinh, G., \& Sharp, B. (2017). Buying brands at both regular price and on promotion over time. Australasian Marketing Journal (AMJ), 25(4), 252-260. https://doi.org/https://doi.org/10.1016/j.ausmj.2017.10.006

Sugiyono. (2016). Metodologi Penelitian Kuantitatif, Kualitatif, dan R\&D. In CV Alfabeta. https://doi.org/https://doi.org/10.3929/ethz-b-000238666

Sugiyono. (2017). Metode Penelitian Bisnis (Pendekatan Kuantitatif, Kualitatif, Kombinasi dan R\&D). In Metodelogi Penelitian.

Sutisna. (2003). Perilaku Konsumen: Teori dan penerapannya dalam Pemasaran. Ghalia Indonesia, Jakarta. https://doi.org/10.1007/BF01013984

Swastha, Basu, I. (2014). Manajemen Pemasaran Modern. In Liberty, Yogyakarta. https://doi.org/10.1017/CBO9781107415324.004

Tjiptono, F. (2004). Prinsip-prinsip Total Quality Service. In book.

Trianah, L., Pranitasari, D., \& Zahrani Marichs, S. (2017). Pengaruh Kualitas Produk dan Kualitas Pelayanan Terhadap Kepuasan Pelanggan dan Loyalitas Pelanggan. Jurnal STEI Ekonomi. https://doi.org/10.36406/jemi.v26i01.201

Udang-Undang Nomor 1 Tahun 2011 tentang Perumahan dan Kawasan Pemukiman. UdangUndang Nomor 1 Tahun 2011 tentang Perumahan dan Kawasan Pemukiman. , (2011).

Zhu, X., Jiao, C., \& Yuan, T. (2019). Optimal decisions on product reliability, sales and promotion under nonrenewable warranties. Reliability Engineering \& System Safety, 192, 106268. https://doi.org/https://doi.org/10.1016/j.ress.2018.09.017 